\title{
Durability Study on High-Performance Fiber-Reinforced Mortar under Simulated Wastewater Pipeline Environment
}

\author{
Tianyu Wang ${ }^{1}$, Yahong Zhao ${ }^{1}$, Baosong Ma ${ }^{2}$ and Cong Zeng ${ }^{1, *}$ \\ 1 Department of Engineering, China University of Geosciences-Wuhan, Wuhan 430074, China; \\ cugwty@cug.edu.cn (T.W.); yhchaos@163.com (Y.Z.) \\ 2 School of Civil Engineering, Sun Yat-Sen University, Zhuhai 519082, China; mabaos@mail.sysu.edu.cn \\ * Correspondence: zengcong@cug.edu.cn
}

check for updates

Citation: Wang, T.; Zhao, Y.; Ma, B.; Zeng, C. Durability Study on

High-Performance Fiber-Reinforced Mortar under Simulated Wastewater Pipeline Environment. Materials 2021, 14, 3781. https://doi.org/ $10.3390 / \mathrm{ma} 14143781$

Academic Editor: Se-Jin Choi

Received: 13 June 2021

Accepted: 3 July 2021

Published: 6 July 2021

Publisher's Note: MDPI stays neutral with regard to jurisdictional claims in published maps and institutional affiliations.

Copyright: (c) 2021 by the authors. Licensee MDPI, Basel, Switzerland. This article is an open access article distributed under the terms and conditions of the Creative Commons Attribution (CC BY) license (https:// creativecommons.org/licenses/by/ $4.0 /)$.

\begin{abstract}
The acid-alkaline-inducd corrosive environments inside wastewater concrete pipelines cause concrete structural deterioration and substantial economic losses all over the world. Highperformance concrete/mortar (HPC) was designed to have better resistance to corrosive environments, with enhanced service life. However, the durability of HPC in wastewater pipeline environments has rarely been studied. A high-performance mortar mixture (M) reinforced by supplemental materials (including fly ash and silica fume) and polyvinyl alcohol (PVA) fibers, together with a mortar mixture $(\mathrm{P})$ consisting of cement, sand and water with similar mechanical performance, were both designed and exposed to simulated wastewater pipeline environments. The visual appearance, dimensional variation, mass loss, mechanical properties, permeable pore volume, and microstructure of the specimens were measured during the corrosion cycles. More severe deterioration was observed when the alkaline environment was introduced into the corrosion cycles. Test results showed that the $\mathrm{M}$ specimens had less permeable pore volume, better dimensional stability, and denser microstructure than the P specimens under acid-alkaline-induced corrosive environments. The mass-loss rates of the M specimens were $66.1-77.2 \%$ of the P specimens after 12 corrosion cycles. The compressive strength of the M specimens was 25.5-37.3\% higher than the P specimens after 12 cycles under corrosive environments. Hence, the high-performance mortar examined in this study was considered superior to traditional cementitious materials for wastewater pipeline construction and rehabilitation.
\end{abstract}

Keywords: durability; high-performance concrete/mortar; wastewater pipeline environments; corrosion

\section{Introduction}

Expanding urbanization spikes the increasing development of underground space [1]. For example, the Singapore government has listed the planning and construction of underground space as a strategic development policy [2]. Elsewhere, other cities, such as Zurich, Kuala Lumpur, and Hong Kong, are trying to have a better understanding of underground utilities by drawing a complex map of the underground space [3]. These underground infrastructures, including pipelines, utility tunnels, and other networks, are the lifelines of a city, connecting different districts like blood vessels [4]. Meanwhile, underground pipeline accidents could cause deleterious social events and economic losses. For example, the loss due to a pipeline accident in China can total billions of dollars, and a 6-billion-gallon loss of treated water per day was estimated in the U.S. due to pipeline failure [5,6]. The long-term operation, corrosion environments, poor design, and humankind's engineering activities may be the causes of deterioration and failure in a pipeline [7]. Especially in the sewer pipeline system, the complex biological, physical, and chemical processes that happen inside the pipeline easily result in structural deterioration within its design lifetime [8]. Studies show that sewer pipeline system rehabilitation work cost over USD 549 million in Germany, USD 120.7 million in the UK per year, and is estimated to be USD 390 billion in the next 20 years in the USA [9-11]. In Hamburg, the sewer concrete pipe corrosion rate was more than $6 \mathrm{~cm} /$ year in depth [12]. A field study showed that $100 \mathrm{~mm}$-depth 
corrosion was observed in the sewer system that was built in 2001 in Edmonton, Canada. The rehabilitation cost was about USD 13.9 million in 2015 [13].

Extensive studies have been conducted to facilitate a better understanding and control of the deterioration process of sewer concrete pipeline structures, through a variety of research works [14-16]. Some chemical acids were used as the corrosive agents of the concrete material corrosion. The hydrochloric acid was found to be aggressive to the concrete structure and the steel reinforcement [17]. As for sulfuric acid, the expansibility of its corrosion product could cause secondary damage to the matrix $[18,19]$. Biological acid produced by Thiobacillus Thiooxidans and other microorganisms was used to simulate the corrosive environment in sewer concrete pipes [20-22]. Research showed that the corrosion processes of biological acid and chemical acid were nearly the same, except for the complicated preparatory stages of bio-acid corrosion [23]. Hydrochloric acid was chosen as the acid medium in this study. It was also proven that the changes in temperature and humidity that resulted in dry-wet cycles and freeze-thaw cycles could lead to the accelerated corrosion of the concrete [24-26]. The dry-wet cycles were more common and obvious in the sewer system, especially around the waterline area, than other environmental indicators [27]. Thus, the dry-wet cycles were included as one of the corrosive environments in this study.

However, it should be noticed that alkaline wastewater was found to be intermittently transported in the wastewater pipe, while usually an alkaline environment was ignored in the previous long-term studies of the sewer concrete corrosion because of the highly alkaline concrete material $[28,29]$. However, faster deterioration of the sewer concrete pipe was found around the waterline area under biogenic acid corrosion and alkaline flow with a dry-wet cycle [30]. Until now, most attention was only paid to the acidic corrosion environment [31-33], which might make the experimental work and numerical model less practical [32]. Therefore, a dry-wet acid-alkaline cycle condition was designed in this study to simulate the corrosive environment around the waterline area of the wastewater pipeline.

The concept of high-performance concrete (HPC) was developed to fulfill the need for concrete structures with high durability and long service life [34]. Supplemental materials (e.g., fly ash, silica fume), fine aggregate, and fibers were generally introduced into this type of cementitious mixture, with good mechanical and durability performances under corrosive environments $[35,36]$. This kind of cementitious material has been used in the underground infrastructures' rehabilitation project [37]. A high-performance fiberreinforced mortar was designed as a research object in this study. Fly ash (FA), silica fume (SF) and PVA fibers were used to enhance the durability of the material under a simulated corrosion wastewater environment [38,39].

This paper aims to study the deterioration process of cementitious material in a new acid-alkaline cycle corrosive environment, and then develop a high-performance fiber-reinforced mortar that has better resistance to the extremely corrosive environment. The visual appearance, dimensional stability, mass loss, compressive behavior, and microstructure of the cementitious materials were studied during the experimental cycles. The high-performance fiber-reinforced mortar designed in this paper may become a good solution to address problems that happened in the wastewater concrete pipe system. The findings of this study provide a technical reference for understanding the concrete corrosion process and guiding future construction and rehabilitation work of wastewater concrete pipe structures.

\section{Materials and Methods}

\subsection{Materials}

Portland cement ((PC), from Fujian Longlin Group Company Ltd., Fujian, China) conforming to GB/T 14684-2011, was used [40]. The fly ash (FA), which contained $\mathrm{SiO}_{2}$ $(58 \%), \mathrm{Al}_{2} \mathrm{O}_{3}(30 \%), \mathrm{Fe}_{2} \mathrm{O}_{3}(4.3 \%), \mathrm{CaO}(1.5 \%), \mathrm{MgO}(2.8 \%), \mathrm{Na}_{2} \mathrm{O}(3.2 \%)$, and the silica fume (SF) which contained $\mathrm{SiO}_{2}(\geq 98 \%), \mathrm{Al}_{2} \mathrm{O}_{3}(\leq 0.7 \%), \mathrm{Fe}_{2} \mathrm{O}_{3}(\leq 0.6 \%), \mathrm{CaO}(\leq 0.5 \%)$, 
$\mathrm{MgO}(\leq 0.2 \%)$, both from Wuhan Newreach Materials (Wuhan, China), were used. The PVA fibers (diameter: $40 \mu \mathrm{m}$, length: $12 \mathrm{~mm}$ ) have a 1.6 GPa tensile strength and Young's modulus of more than $38 \mathrm{GPa}$, and were sourced from Kuraray (Tokyo, Japan) and are named Kuralon K-II. The volume fraction of PVA fibers was 1.5\%. Silica sand ((SS), silicon dioxide content $\geq 99.3 \%$, Hengwang Environmental Protection, Zhengzhou, China) conforming to GB/T 14684-2011 was used [41]. A polycarboxylate superplasticizer from SUNBO (Suzhou, China) with a water-reducing effect of 30\% was used.

Two kinds of cementitious specimens were prepared, as shown in Table 1. The M group was designed with PVA fibers, while the P group was designed to have a similar mechanical performance to the $\mathrm{M}$ group. The mixture design is listed in Table 1.

Table 1. Mixture design of $\mathrm{M}$ and $\mathrm{P}$ specimens (weight ratio).

\begin{tabular}{ccc}
\hline Mixture ID & M & P \\
\hline PC (Portland cement) & 1 & 1 \\
FA (fly ash) & 0.19 & - \\
SF (silica fume) & 0.08 & - \\
SS (silica sand) & 1.4 & 1.4 \\
PVA (\% by volume) (polyvinyl alcohol) & 1.5 & - \\
Water/cement ratio & 0.26 & 0.26 \\
SP (\% by weight) (superplasticizer) & 0.12 & 0.12 \\
\hline
\end{tabular}

\subsection{Curing Environments}

The $\mathrm{pH}$ value of the underground pipeline could be reduced by around 1-2 [12], while alkaline wastewater sometimes might have a PH greater than 10 [42]. To simulate the accelerated corrosion environment in a water drainage pipe, 38\% hydrochloric acid $(\mathrm{HCl})$, and sodium hydroxide from Xilong Scientific (Guangdong, China) were used to maintain the $\mathrm{PH}$ of the acidic environment at around 1 and the alkaline environment at around 13. The corrosion solution would penetrate the matrix through the " $\sqrt{ }$ " marked surfaces (Figure 1). Epoxy resin (E51) (Beijing, China) from Beijing Yuhong Waterproof Technology Co. Ltd. was used to seal the other surfaces.

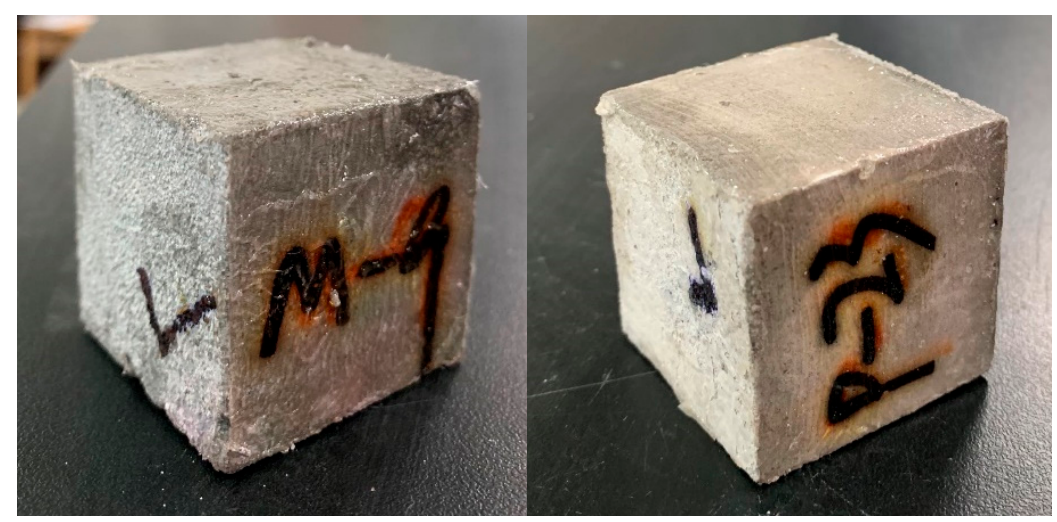

Figure 1. Sealed specimens in the experimental work, the ' $\sqrt{ }$ ' marked surface was the only unsealed surface.

Three different curing environments were designed in Table 2. The specimens were cured in water for the first 7 days, then they were immersed separately in environments I, II and III. In environment I, the specimens were cleaned with water and dried at $20^{\circ} \mathrm{C}$ for $24 \mathrm{~h}$ after immersion in the acid environment for 4.5 days. Then in the next 4.5 days, the specimens were put into the alkaline environment before the next cycle. The $\mathrm{PH}$ values of the acid/alkaline solution were checked with a $\mathrm{pH}$ meter (PHS-3C from LeiCi, Hangzhou, China) and maintained every day at around $\mathrm{pH} 1$ and 13 , respectively. The $\mathrm{M}$ and $\mathrm{P}$ specimens were also tested, respectively, after curing in different environments, and comparative analyses were carried out as shown in the following part. 
Table 2. Curing environments of the experimental study.

\begin{tabular}{|c|c|c|c|c|}
\hline \multirow{2}{*}{ No. } & \multirow{2}{*}{ Curing Environment } & \multicolumn{3}{|c|}{ The 10-Day Cycle } \\
\hline & & 4.5 Days & $24 \mathrm{~h}$ & 4.5 Days \\
\hline I & Acid/Alkaline cycle & $\begin{array}{l}\mathrm{PH}=1 \text { acid } \\
\text { environment }\end{array}$ & Dry at $20^{\circ} \mathrm{C}$ & $\begin{array}{c}\mathrm{PH}=13 \text { alkaline } \\
\text { environment }\end{array}$ \\
\hline II & Acid-only & \multicolumn{3}{|c|}{$\mathrm{PH}=1$ acid environment } \\
\hline III & Tap water & \multicolumn{3}{|c|}{ Tap water (PH around 7) } \\
\hline
\end{tabular}

\subsection{Test Procedures}

The visual and mass changes of the specimens were tracked and recorded during the cyclic exposure. The height change perpendicular to the unsealed surface was recorded using a vernier caliper.

The continuous mass-loss rate $\left(R_{m}\right)$ was determined as follows [43]:

$$
\mathrm{R}_{\mathrm{m}}=\frac{\mathrm{W}_{0}-\mathrm{W}_{\mathrm{i}}}{\mathrm{W}_{0}} \times 100 \%, \mathrm{i}=1,2, \ldots, 12
$$

where $\mathrm{W}_{0}$ was the initial weight of the specimens before the cycles, while $\mathrm{W}_{\mathrm{i}}$ was the weight of the specimens after being exposed to $i$ corrosion cycles. The measurement was carried out by scales with an accuracy of $0.1 \mathrm{mg}$ [44]. The permeable porosity of the specimens was measured per ASTM C642 [45].

The cubes $(40 \times 40 \times 40 \mathrm{~mm})$ were tested with a displacement control scheme (SANS YAW4605, MTS System (China) Co., Ltd., Shenzhen, China) to obtain the whole process of compressive behavior (see Figure 2).

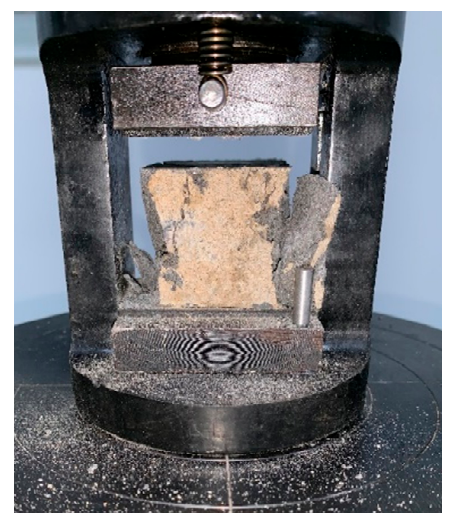

Figure 2. Compression-testing machine.

The specimens were prepared and Au-sputtered, then measured by JSM-6701F to obtain the FESEM (field emission scanning electron microscope, JEOL Ltd., Tokyo, Japan) images. The crystal structure of the corrosion products was characterized by X-ray diffraction (XRD) using an X'PERT PRO (Philips Corp., Eindhoven, The Netherlands) diffractometer at a glancing angle of $1^{\circ}$ with $\mathrm{Cu} \mathrm{K} \alpha$ radiation $(\lambda=0.154 \mathrm{~nm})$ at $2 \theta$ ranging from 5 to 60 .

\section{Results and Discussion}

\subsection{Visual Appearance and Height Loss}

The visual appearance changes of the specimens under the corrosion environments are presented in Figure 3. The brownish areas showed up on the surfaces of the specimens because of the iron ion precipitation [46]. The fibers and aggregates were exposed as the corrosion cycles increased. In the later stage, the $\mathrm{M}$ specimens under environment I seemed to be more damaged than the specimens under environment II [47]. Both $\mathrm{M}$ and $\mathrm{P}$ specimens became soft after 12 acid-alkaline cycles, while the surface remained a little bit harder in environment II. 


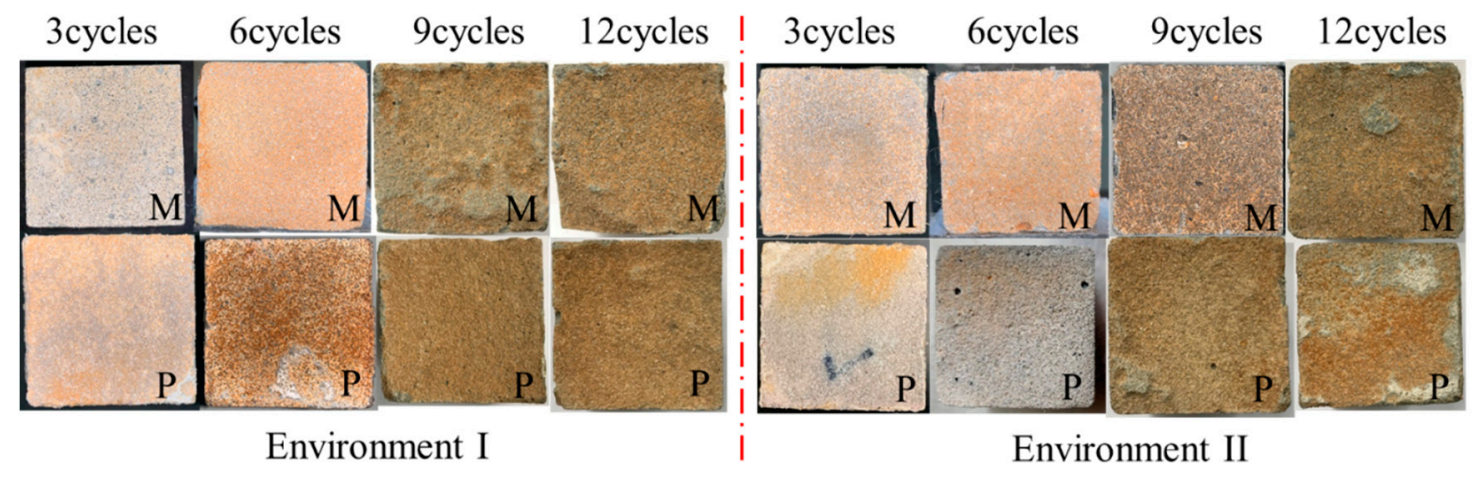

Figure 3. Surface variations of the specimens under corrosion cycles.

The size change of the specimens in the vertical direction before and after the corrosion cycles were measured by a vernier caliper (Figure 4). The size of $\mathrm{M}$ specimens in the vertical direction became $93.3 \%$ and $90.8 \%$ of the original ones after 12 cycles of corrosion in environments I and II, respectively. The P specimens lost $8.5 \%$ and $11.7 \%$ height in the vertical direction under 12 cycles in environments I and II, respectively. The height loss of the M specimens was $79.2 \%$ and $79.9 \%$ of $\mathrm{P}$ specimens, respectively. The height loss of the $\mathrm{M}$ and $\mathrm{P}$ specimens under environment I was $26.2 \%$ and $37.2 \%$ more than the specimens in environment II. Worse visual deterioration and height loss of cement specimens were observed under environment I. The results showed that the $\mathrm{M}$ specimens showed a better performance regarding visual appearance and dimensional stability under corrosive environments.

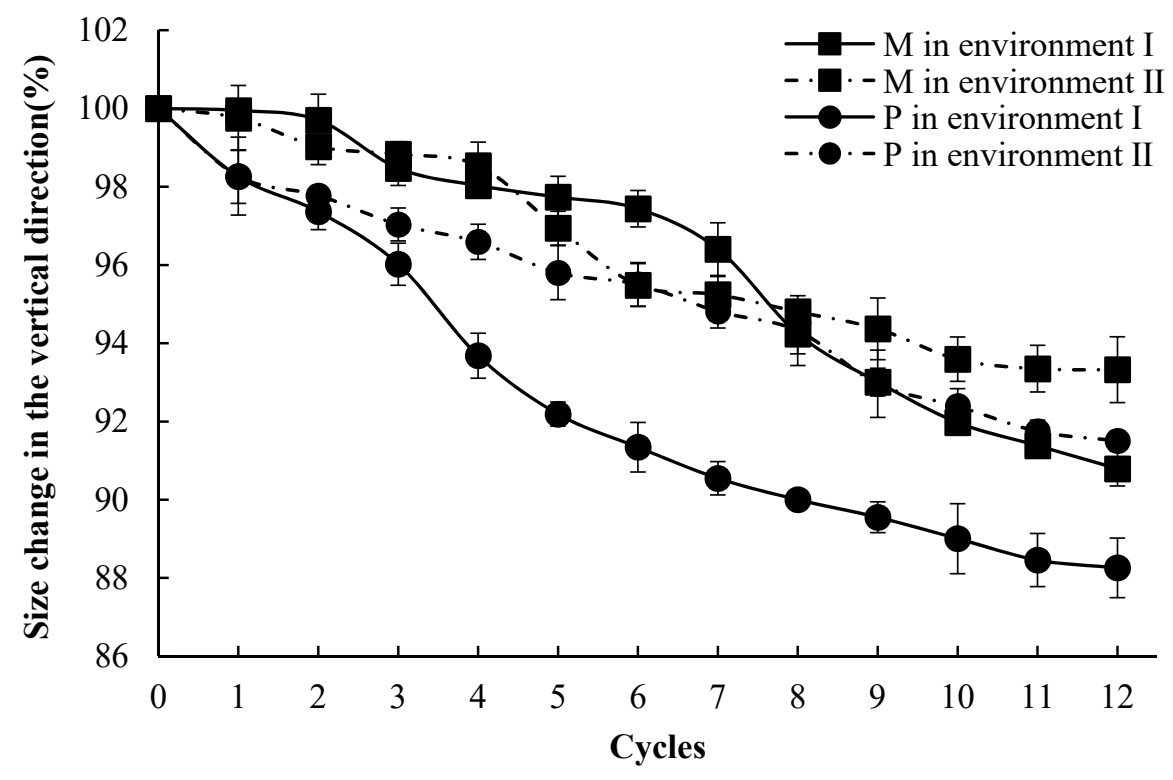

Figure 4. The size change of the specimens under environments I and II.

\subsection{Mass Loss Ratio}

Except for environment III, a significant mass loss could be observed in both $\mathrm{M}$ and $\mathrm{P}$ specimens under environments I and II. Figure 5 shows the change of the mass-loss ratio of the specimens during 12 corrosion cycles. After 12 cycles in environment II, the mass-loss rates of the $\mathrm{P}$ and $\mathrm{M}$ groups were $6.2 \%$ and $4.1 \%$, respectively. In addition, the mass-loss rates of $\mathrm{P}$ and $\mathrm{M}$ under environment $\mathrm{I}$ became $9.2 \%$ and $7.1 \%$, respectively. The mass-loss rates of the $\mathrm{M}$ specimens were $66.1 \%$ and $77.2 \%$ of the P specimens after 12 corrosion cycles in environments I and II, respectively. 


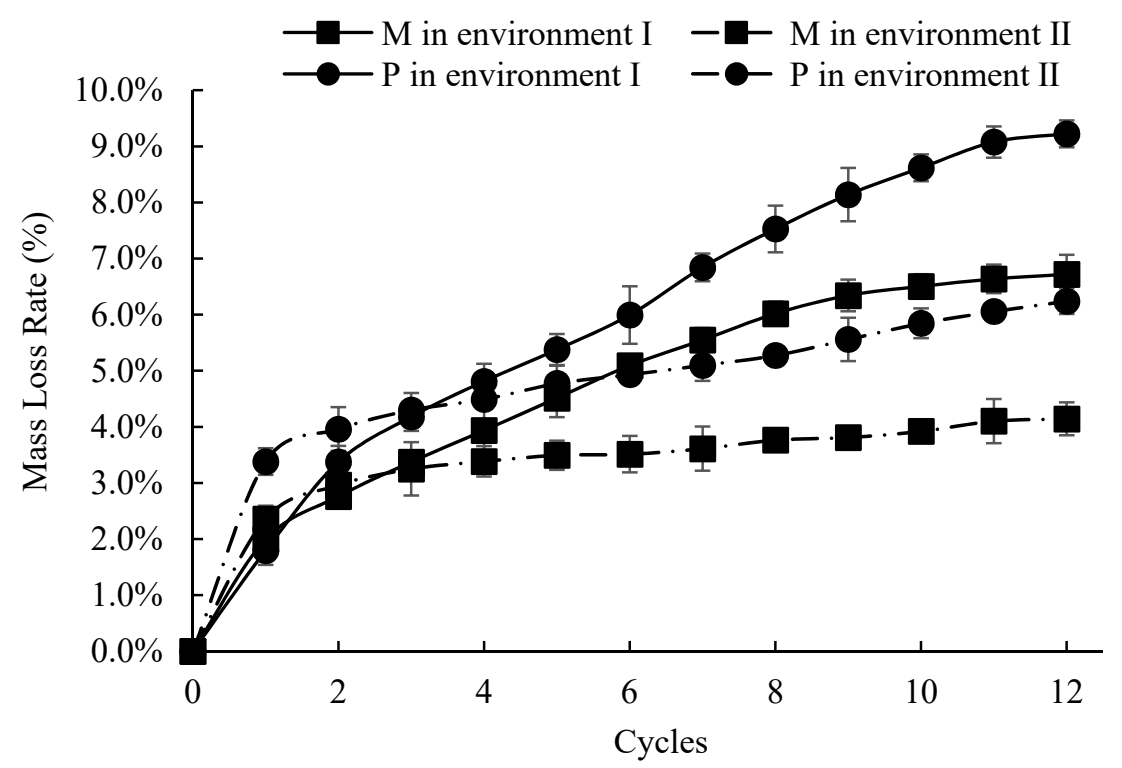

Figure 5. The mass-loss rates of the specimens under 12 cycles of environments I and II.

The trends of the mass-loss rates were also slightly different in the two different corrosion environments. In environment II, the curve rises rapidly in the first 1-2 cycles and then tends to be flat in the end. This indicated that the corroded layer slowed down the corrosion rate with the increase of corrosion cycle numbers [48]. Although a smaller rising trend of the mass loss rate curve was observed during the early period of environment I, the rising trend became higher in the later stage. This indicated that the delayed action of the corroded layer might be weakened under the alkaline environment of environment I.

\subsection{The Permeable Pore Volume}

Figure 6 presented the permeable pore volumes for specimens before and after the corrosion cycles. As compared to the $\mathrm{P}$ specimens, introducing fiber into the $\mathrm{M}$ specimens increased the pore volumes before the corrosion cycles. The pore volumes of all specimens significantly increased after the corrosion cycles. The total pore volume of $\mathrm{M}$ and $\mathrm{P}$ specimens after 12 cycles in environment I was increased by $37.9 \%$ and $19.7 \%$ compared with specimens under environment II. The total permeable pore volume of $\mathrm{M}$ specimens under 12 cycles in environments I and II were $54.7 \%$ and $47.3 \%$ of the P specimens, respectively. This indicated that the incorporation of FA and silica fume densified the matrix of $\mathrm{M}$ specimens, thus accounting for the enhanced resistance to the corrosive environments [49-52].

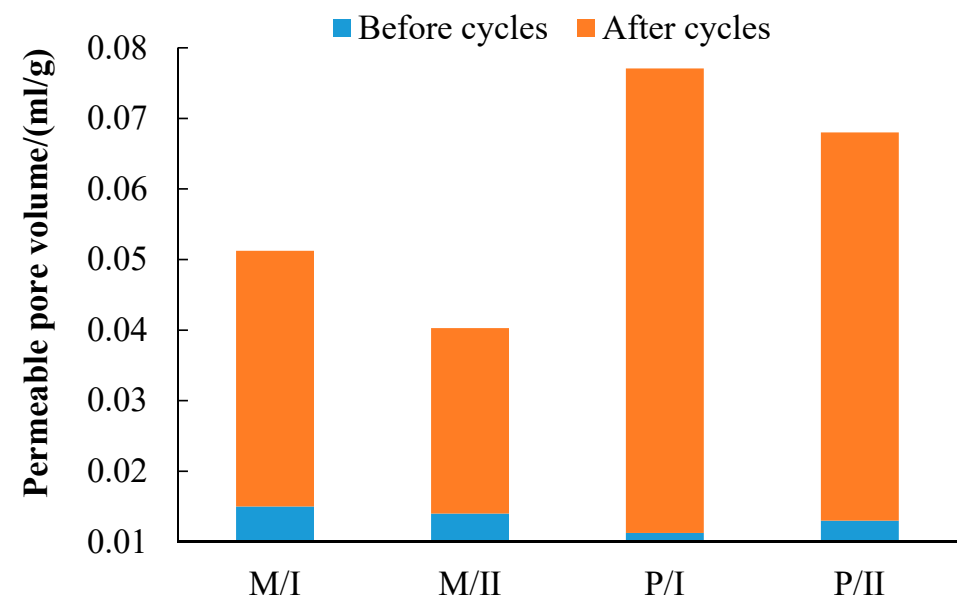

Figure 6. The permeable pore volume of specimens before and after corrosion cycles. 


\subsection{Compressive Strength}

Figure 7 showed the compressive strength changes of the $\mathrm{M}$ and $\mathrm{P}$ specimens immersed in environments I, II and III. The compressive strength of the M and P specimens after $120 \mathrm{~d}$ in environment III was increasing from 78.5 and $80.5 \mathrm{MPa}$ to 96.8 and $102.5 \mathrm{MPa}$, respectively. After 2 3 cycles exposed in environment II, the compressive strength of the $\mathrm{M}$ and $\mathrm{P}$ specimens increased to a peak and decreased subsequently (Figure $7 \mathrm{~b}$ ). A similar trend was observed in environment III, but the compressive strength decreased more rapidly in the late stage of the corrosion. After 12 cycles, the compressive strength of the P group was only $79.6 \%$ and $72.9 \%$ of the M group under environments I and II, respectively. The lower mass-loss rates of the $\mathrm{M}$ group compared to the $\mathrm{P}$ group after the corrosion cycles can be attributed to the supplemental materials (fly ash and silica fume) added to the $M$ group [53]. In the first 2-3 cycles, an increasing trend of compressive strength was observed in environments I and II. This indicated that the hydration process defeated the deterioration effect of the corrosive environments in the early curing period [54]. The 12 cycles in environment I reduced the compressive strength by $34.1 \%$ and $54.7 \%$, respectively, for the $\mathrm{M}$ and $\mathrm{P}$ specimens, and the reduction was $22.52 \%$ and $41.7 \%$ in environment II, respectively.

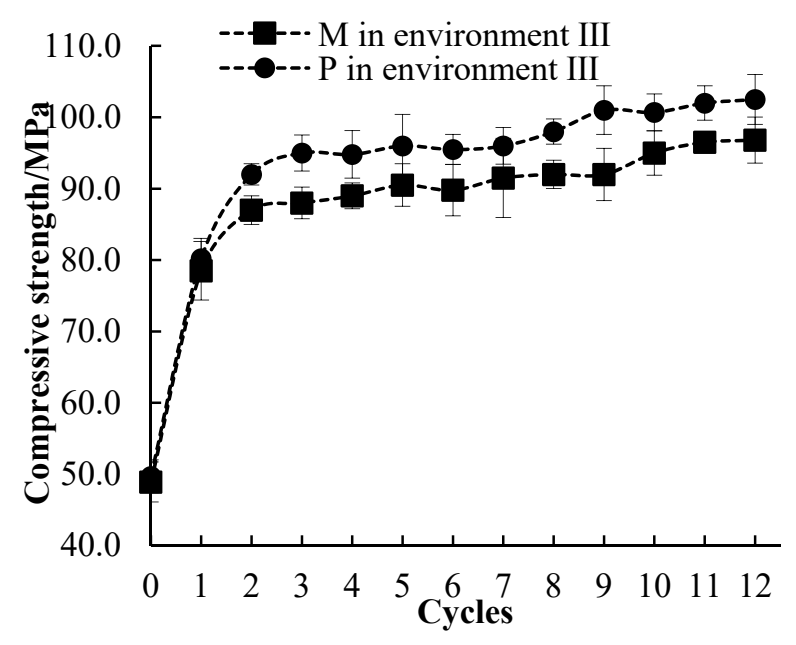

(a)

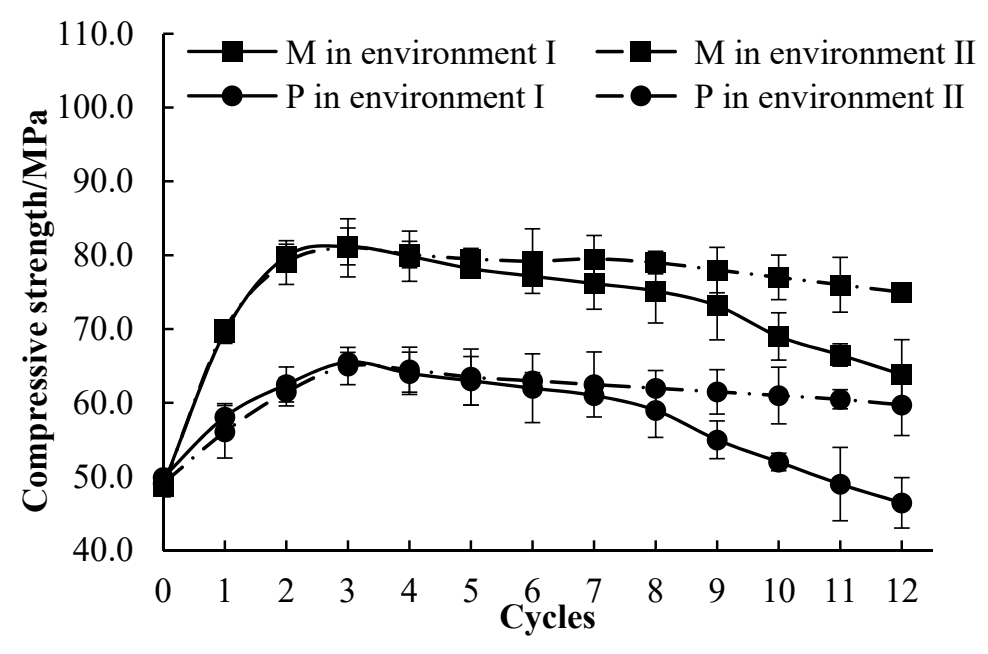

(b)

Figure 7. Compressive strength evolution showing (a) a generally increasing trend in tap water (environment III), but (b) an initial increase followed by a decrease in environments I and II.

The more rapidly decreased trend of the compressive strength of the specimens under environment I indicated that the acid-alkaline cycles could continually cause more damage to the inner cementitious matrix, despite the delaying effect of the corroded layer, especially in the late stages, compared to environment II.

\subsection{XRD and SEM Analysis}

The XRD patterns of the specimens cured in different environments are shown in Figure 8. For $\mathrm{M}$ and $\mathrm{P}$ specimens in tap water, calcium silicate hydrate $(\mathrm{C}-\mathrm{S}-\mathrm{H}$, $\left.2 \theta, 29.4^{\circ}\right), \mathrm{Ca}(\mathrm{OH})_{2}\left(2 \theta, 26.8^{\circ}\right.$ and $\left.47.5^{\circ}\right)$ was identified as a good indicator of cement hydration $[55,56]$. The compact C-S-H and tabular $\mathrm{Ca}(\mathrm{OH})_{2}$ crystal shown in Figure $9 \mathrm{a}, \mathrm{b}$ also contributed to the good physical and mechanical properties of the cement specimens. 


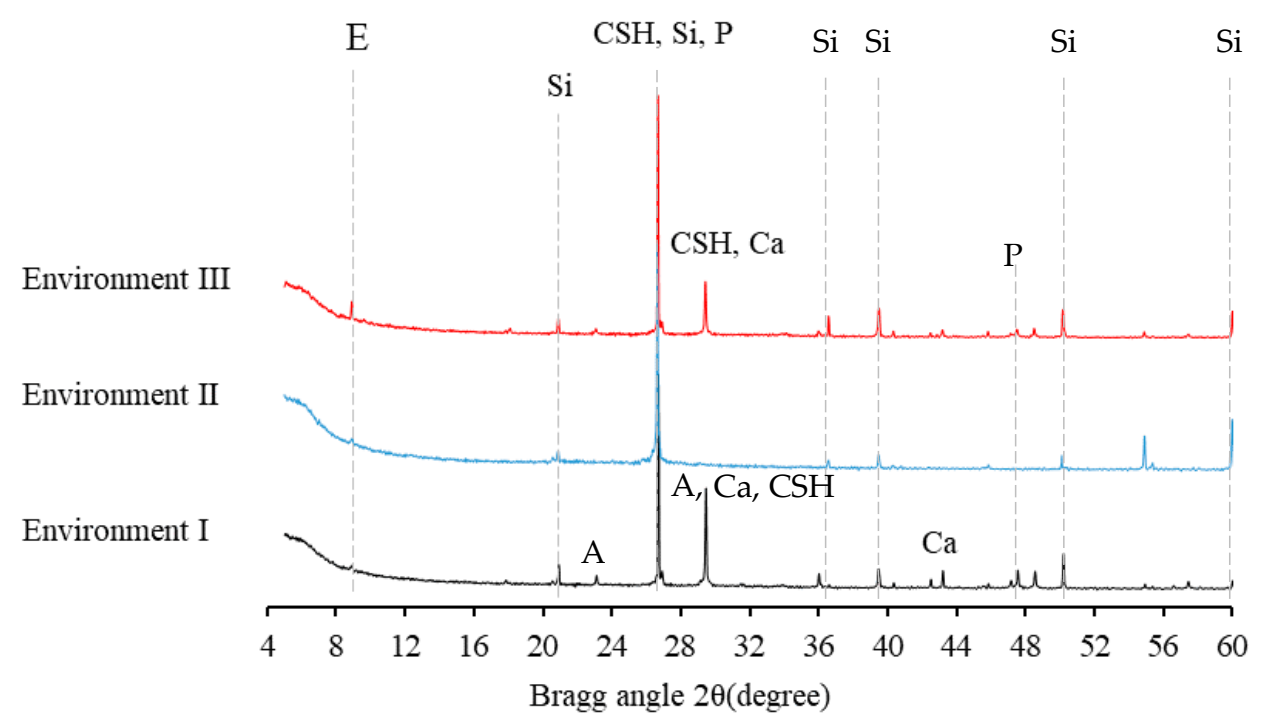

Figure 8. X-ray diffractograms of corrosion products from specimens after immersed in environments I, II and III (E: ettringite, $\mathrm{CSH}$ : calcium silicate hydrate, A: albite, $\left.\mathrm{Ca}: \mathrm{CaCO}_{3}, \mathrm{P}: \mathrm{Ca}(\mathrm{OH})_{2}, \mathrm{Si}: \mathrm{SiO}_{2}\right)$.
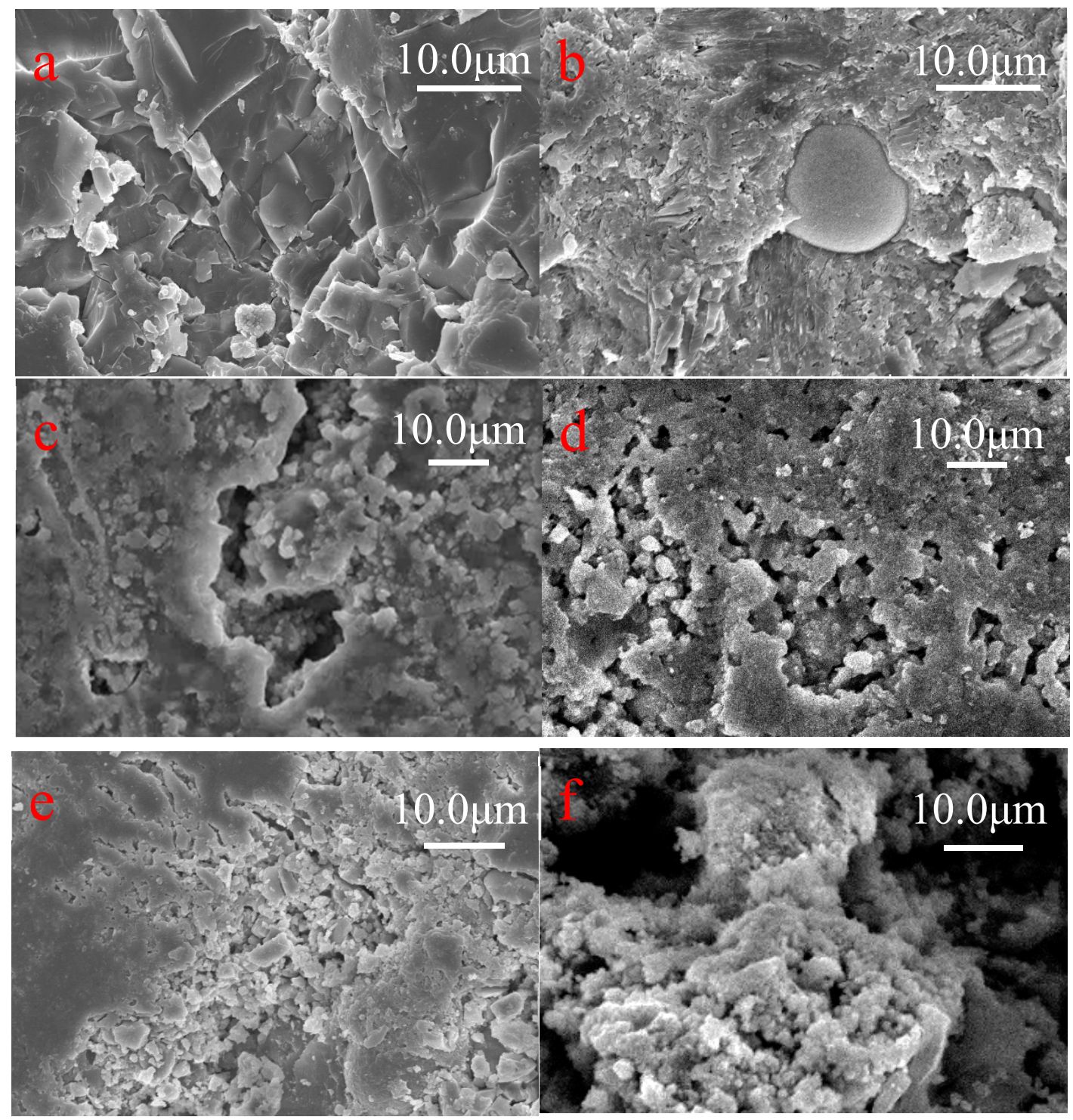

Figure 9. SEM images of $\mathrm{M}$ and P specimens under 12 cycles of environments I (e,f), II (c,d) and III (a,b). 
After exposure to environment II $(\mathrm{HCl}, \mathrm{PH}=1)$, the calcite $\left(\mathrm{CaCO}_{3}, 29.4^{\circ}\right)$, ettringite $\left(\mathrm{Ca}_{6} \mathrm{Al}_{2}\left(\mathrm{SO}_{4}\right)_{3}(\mathrm{OH}) 12 \cdot 26 \mathrm{H}_{2} \mathrm{O}_{8}, 9.0^{\circ}\right)$ and $\mathrm{Ca}(\mathrm{OH})_{2}$ were dissolved by the $\mathrm{H}+$ which was indicated by the significant reduction and absent of peaks at $9.0^{\circ}, 26.8^{\circ}, 29.4^{\circ}$ and $47.5^{\circ}[57,58]$. The silica gel $\left(2 \theta, 20.9^{\circ}, 26.8^{\circ}, 36.6^{\circ}, 39.5^{\circ}, 50.2^{\circ}, 60.0^{\circ}\right)$ was observed in Figure $9 \mathrm{c}$, d with the breaking down of $\mathrm{CSH}$, and the silica gel was identified as the corrosion product accumulating on the surface of the specimens [46]. This phenomenon was conforming to the increase of pore volume and decrease of mass loss and compressive strength.

Compared to the XRD pattern in environment II, the albite $\left(\mathrm{Na}\left(\mathrm{AlSi}_{3} \mathrm{O}_{8}\right), 23.2^{\circ}, 29.5^{\circ}\right)$, $\mathrm{Ca}(\mathrm{OH})_{2}$ and more calcite $\left(2 \theta, 29.5^{\circ}\right)$ were detected in the corrosion product of the specimens under environment I [59]. Unlike the accumulated corrosion products in environment II, the corrosion product under alkaline solution in environment I could create new passages that would accelerate the contact between the acid solution and the intact matrix because of its acid-soluble property (Figure 10). The increasing porosity and non-compact microstructure of the specimens under environments I and II in Figure $9 \mathrm{c}-\mathrm{f}$ showed the deterioration of the specimens at a microscale, which was consistent with the decreasing trend of mass change and compressive strength in the late curing stage.

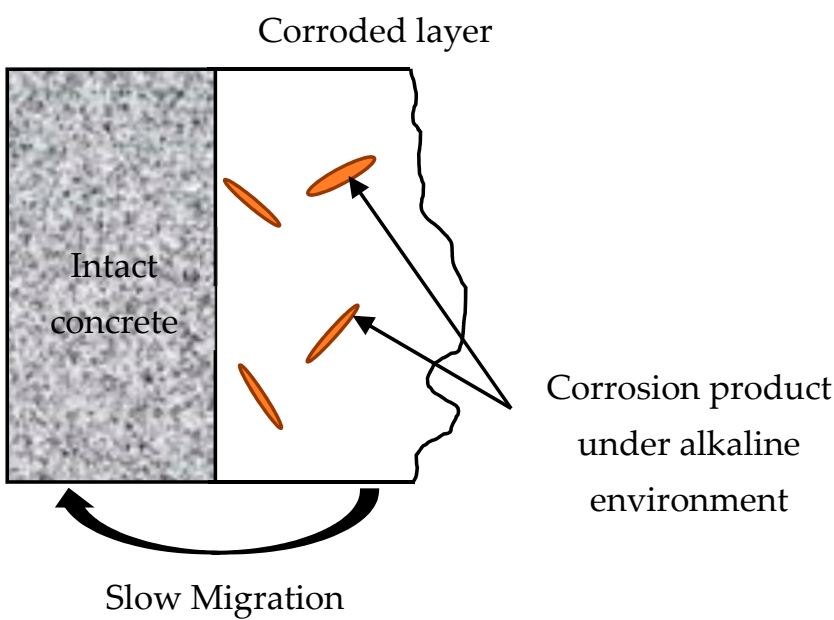

Figure 10. Schematic diagram of the corrosion process under acid/alkaline cycle.

\section{Conclusions}

The durability of the high-performance fiber-reinforced mortar was studied under the simulated corrosive environments of the wastewater pipeline. The combined effects of acid, alkaline and wet-dry cycles were investigated. Conclusions can be drawn as follows.

The high-performance fiber-reinforced mortar (M) group had a better visual appearance than the ordinary mortar $(\mathrm{P})$ group after corrosive cycles; the height loss of the $\mathrm{M}$ group was less than $80 \%$ of the $P$ group after 12 corrosion cycles, which indicated that the M group had better dimensional stability under corrosive environments.

The mass loss ratio and the permeable pore volume of the $\mathrm{M}$ group were $66.1-77.2 \%$ and $47.3-54.7 \%$ of the $\mathrm{P}$ group after 12 corrosion cycles, respectively. After 12 corrosion cycles, the compressive strength of the $\mathrm{P}$ group was less than $79 \%$ of the $\mathrm{M}$ group. The better physical and mechanical performance of the $\mathrm{M}$ group indicated that the $\mathrm{M}$ group had better resistance to the simulated wastewater pipeline environments than the P group.

More serious deterioration was observed on the specimens under environment I (acidalkaline cycles). The height loss of the $\mathrm{M}$ and $\mathrm{P}$ groups under environment I was $26.2 \%$ and $37.2 \%$ more than the height loss under environment II. The mass loss ratio of the $\mathrm{M}$ and P groups was $4.1 \%$ and $6.2 \%$, respectively, under environment II but increased to $7.1 \%$ and $9.2 \%$ under environment $\mathrm{I}$. The total pore volume of the $\mathrm{M}$ and $\mathrm{P}$ specimens after 12 cycles in environment I was increased by $37.9 \%$ and $19.7 \%$, respectively, compared with specimens under environment II. The 12 cycles in environment I reduced the compressive strength by $34.1 \%$ and $54.7 \%$ for $\mathrm{M}$ and $\mathrm{P}$ specimens, the reduction was $22.52 \%$ and 
$41.7 \%$ in environment II, respectively. A greater decreasing trend was observed in the compressive strength curve in the later stage of environment I. The acid-soluble corrosion product (albite) in the alkaline solution could become passages under the following acid environment, which could weaken the delaying effect of the corroded layer on the matrix deterioration rate.

This high-performance fiber-reinforced mortar could become an ideal choice in the wastewater pipeline construction work, according to the experimental results. The experimental work can also provide guidance for wastewater pipeline design and numerical study, based on the high-performance fiber-reinforced mortar under wastewater pipeline environments. Further, more research, such as field tests, needs to be performed to obtain more realistic data.

Author Contributions: Conceptualization, T.W. and C.Z.; methodology, T.W.; validation, Y.Z.; investigation, T.W.; resources, C.Z.; data curation, Y.Z.; writing-original draft preparation, T.W.; writing-review and editing, T.W., Y.Z. and C.Z.; supervision, B.M.; project administration, B.M. and C.Z.; funding acquisition, B.M. and C.Z. All authors have read and agreed to the published version of the manuscript.

Funding: This research was funded by the National Key R\&D Program of China "Public security risk prevention and emergency response technology and equipment": Research and demonstration of urban underground utility tunnel safety prevention and control technology, grant number 2017YFC0805006.

Institutional Review Board Statement: Humans or animals are not involved in this study.

Informed Consent Statement: Humans are not involved in this study.

Data Availability Statement: The data presented in this study are openly available in ASCE at American's infrastructure report card 2021 [6].

Acknowledgments: The authors are very grateful to Duo Zhang for his invaluable advice and suggestions. The authors are very grateful for the technical support provided by Xiamen Anyue Trenchless Engineering Technology Co., Ltd.

Conflicts of Interest: The authors declare no conflict of interest. The funders had no role in the design of the study, in the collection, analyses, or interpretation of data, in the writing of the manuscript, or in the decision to publish the results.

\section{References}

1. Broere, W. Urban underground space: Solving the problems of today's cities. Tunn. Undergr. Space Technol. 2016, 55, 245-248. [CrossRef]

2. Zhou, Y.; Zhao, J. Assessment and planning of underground space use in Singapore. Tunn. Undergr. Space Technol. 2016, 55, 249-256. [CrossRef]

3. Jaw, S.W.; Van Son, R.; Soon, V.K.H.; Schrotter, G.; Kiah, R.L.W.; Ni, S.T.S.; Yan, J. The need for a reliable map of utility networks for planning underground spaces. In Proceedings of the 2018 17th International Conference on Ground Penetrating Radar (GPR), Rapperswil, Switzerland, 18-21 June 2018.

4. Wang, T.; Tan, L.; Xie, S.; Ma, B. Development and applications of common utility tunnels in China. Tunn. Undergr. Space Technol. 2018, 76, 92-106. [CrossRef]

5. Ma, B. Trenchless Pipeline Rehabilitation and Renewal Technology; China Communications Press: Beijing, China, 2014.

6. ASCE American's Infrastructure Report Card 2021: America's Infrastructure Scores a C. Available online: https:// infrastructurereportcard.org (accessed on 5 March 2021).

7. Zeng, C.; Ma, B. Analytic Mode for Predicting the Failure risk of pipeline System. In Proceedings of the ICPTT 2009: Advances and Experiences with Pipelines and Trenchless Technology for Water, Sewer, Gas, and Oil Applications, Shanghai, China, 18-21 October 2009; International Conference on Pipelines and Trenchless Technology (ICPTT): Shanghai, China, 2009; Volume 89, pp. 17-27.

8. Ma, B.; Najafi, M. Development and applications of trenchless technology in China. Tunn. Undergr. Space Technol. 2008, 23, 476-480. [CrossRef]

9. Sand, W. Importance of hydrogen sulfide, thiosulfate, and methylmercaptan for growth of thiobacilli during simulation of concrete corrosion. Appl. Environ. Microbiol. 1987, 53, 1645-1648. [CrossRef] [PubMed]

10. Berger, C.; Falk, C.; Hetzel, F.; Pinnekamp, J.; Roder, S.; Ruppelt, J. State of the Sewer System in Germany-Results of the DWA Survey 2015. KA Korresp. Abwasser Abfall 2016, 63, 15-17. 
11. Berger, C.; Lohaus, J. Zustand der Kanalisation in Deutschland-Ergebnisse der DWA-Umfrage 2004. Korresp. Abwasser 2005, 52, 528-539.

12. Sand, W.; Bock, E. Concrete corrosion in the Hamburg sewer system. Environ. Technol. 1984, 5, 517-528. [CrossRef]

13. Wu, L.; Hu, C.; Liu, W.V. The sustainability of concrete in Sewer tunnel-A narrative review of acid corrosion in the city of Edmonton, Canada. Sustainability 2018, 10, 517. [CrossRef]

14. Grengg, C.; Mittermayr, F.; Ukrainczyk, N.; Koraimann, G.; Kienesberger, S.; Dietzel, M. Advances in concrete materials for sewer systems affected by microbial induced concrete corrosion: A review. Water Res. 2018, 134, 341-352. [CrossRef]

15. Zhang, L.; De Schryver, P.; De Gusseme, B.; De Muynck, W.; Boon, N.; Verstraete, W. Chemical and biological technologies for hydrogen sulfide emission control in sewer systems: A review. Water Res. 2008, 42, 1-12. [CrossRef] [PubMed]

16. Wang, T.; Zeng, C. Study of Cement-Based Superhydrophobic Composite Coating: New Option for Water Drainage Pipeline Rehabilitation. Materials 2020, 13, 5004. [CrossRef] [PubMed]

17. Bahtli, T.; Ozbay, N.S. Corrosion resistances of C30 concrete: Effect of finely ground bronze sawdust waste. Mater. Chem. Phys. 2020, 243, 122588. [CrossRef]

18. Attiogbe, E.K.; Rizkalla, S.H. Response of concrete to sulfuric acid attack. ACI Mater. J. 1988, 85, 481-488.

19. Gutiérrez-Padilla, M.G.D.; Bielefeldt, A.; Ovtchinnikov, S.; Hernandez, M.; Silverstein, J. Biogenic sulfuric acid attack on different types of commercially produced concrete sewer pipes. Cem. Concr. Res. 2010, 40, 293-301. [CrossRef]

20. Islander, R.L.; Devinny, J.S.; Mansfeld, F.; Postyn, A.; Shih, H. Microbial ecology of crown corrosion in sewers. J. Environ. Eng. 1991, 117, 751-770. [CrossRef]

21. Jiang, G.; Zhou, M.; Chiu, T.H.; Sun, X.; Keller, J.; Bond, P.L. Wastewater-enhanced microbial corrosion of concrete sewers. Environ. Sci. Technol. 2016, 50, 8084-8092. [CrossRef]

22. Kaushal, V.; Najafi, M.; Love, J. Qualitative investigation of microbially induced corrosion of concrete in sanitary sewer pipe and manholes. Proc. ASCE Pipelines 2018, 2018, 768-775.

23. Huber, B.; Hilbig, H.; Mago, M.M.; Drewes, J.E.; Müller, E. Comparative analysis of biogenic and chemical sulfuric acid attack on hardened cement paste using laser ablation-ICP-MS. Cem. Concr. Res. 2016, 87, 14-21. [CrossRef]

24. He, R.; Zheng, S.; Gan, V.J.; Wang, Z.; Fang, J.; Shao, Y. Damage mechanism and interfacial transition zone characteristics of concrete under sulfate erosion and Dry-Wet cycles. Constr. Build. Mater. 2020, 255, 119340. [CrossRef]

25. Wang, Y.; Cao, Y.; Zhang, P.; Ma, Y.; Zhao, T.; Wang, H.; Zhang, Z. Water absorption and chloride diffusivity of concrete under the coupling effect of uniaxial compressive load and freeze-thaw cycles. Constr. Build. Mater. 2019, 209, 566-576. [CrossRef]

26. Han, T.; Wang, X.; Li, D.; Han, N.; Xing, F. Damage and degradation mechanism for single intermittent cracked mortar specimens under a combination of chemical solutions and dry-wet cycles. Constr. Build. Mater. 2019, 213, 567-581. [CrossRef]

27. RashCid, S.S.; Liu, Y.Q. Assessing environmental impacts of large centralized wastewater treatment plants with combined or separate sewer systems in dry/wet seasons by using LCA. Environ. Sci. Pollut. Res. 2020, 27, 1-17.

28. Liang, X.; Lu, Y.; Li, Z.; Yang, C.; Niu, C.; Su, X. Bentonite/carbon composite as highly recyclable adsorbents for alkaline wastewater treatment and organic dye removal. Microporous Mesoporous Mater. 2017, 241, 107-114. [CrossRef]

29. Roghanian, N.; Banthia, N. Development of a sustainable coating and repair material to prevent bio-corrosion in concrete sewer and waste-water pipes. Cem. Concr. Compos. 2019, 100, 99-107. [CrossRef]

30. Mori, T.; Nonaka, T.; Tazaki, K.; Koga, M.; Hikosaka, Y.; Noda, S. Interactions of nutrients, moisture and pH on microbial corrosion of concrete sewer pipes. Water Res. 1992, 26, 29-37. [CrossRef]

31. Monteny, J.; De Belie, N.; Vincke, E.; Verstraete, W.; Taerwe, L. Chemical and microbiological tests to simulate sulfuric acid corrosion of polymer-modified concrete. Cem. Concr. Res. 2001, 31, 1359-1365. [CrossRef]

32. Li, B.; Wang, F.; Fang, H.; Yang, K.; Zhang, X.; Ji, Y. Experimental and numerical study on polymer grouting pretreatment technology in void and corroded concrete pipes. Tunn. Undergr. Space Technol. 2021, 113, 103842. [CrossRef]

33. De Belie, N.; Monteny, J.; Beeldens, A.; Vincke, E.; Van Gemert, D.; Verstraete, W. Experimental research and prediction of the effect of chemical and biogenic sulfuric acid on different types of commercially produced concrete sewer pipes. Cem. Concr. Res. 2004, 34, 2223-2236. [CrossRef]

34. Li, J.; Wu, Z.; Shi, C.; Yuan, Q.; Zhang, Z. Durability of ultra-high performance concrete-A review. Constr. Build. Mater. 2020, 255, 119296. [CrossRef]

35. Richard, P.; Cheyrezy, M. Reactive powder concretes with high ductility and 200-800 MPa compressive strength. Symp. Pap. 1994, 144, 507-518.

36. Richard, P.; Cheyrezy, M. Composition of reactive powder concretes. Cem. Concr. Res. 1995, 25, 1501-1511. [CrossRef]

37. Zhou, W.; Kong, Y. Centrifugal spraying rehabilitation technology has been used in the world's largest trenchless rehabilitation project for manholes. China Trenchless Technol. 2015, 3, 51-54.

38. Zhang, P.; Li, Q.F. Effect of polypropylene fiber on durability of concrete composite containing fly ash and silica fume. Compos. Part B Eng. 2013, 45, 1587-1594. [CrossRef]

39. Mahdavi, M.; Abolmaali, A.; Ghahremannejad, M. The effects of $\mathrm{pH}$ and temperature on compressive strength of synthetic fiber-reinforced concrete cylinders exposed to sulfuric acid. Adv. Civ. Eng. Mater. 2018, 7, 403-413.

40. AQSIQ. SAC Common Portland Cement, GB 175-2007; China Standard Press: Beijing, China, 2007.

41. GB/T 14684-2011, Sand for Construction. Ministry of Housing and Urban-Rural Development of the People's Republic of China; Standards Press of China: Beijing, China, 2011. 
42. Barakan, S.; Aghazadeh, V. Structural modification of nano bentonite by aluminum, iron pillarization and 3D growth of silica mesoporous framework for arsenic removal from gold mine wastewater. J. Hazard. Mater. 2019, 378, 120779. [CrossRef]

43. Sabour, M.; Dezvareh, G.; Bazzazzadeh, R. Corrosion prediction using the weight loss model in the sewer pipes made from sulfur and cement concretes and Response Surface Methodology (RSM). Constr. Build. Mater. 2019, 199, 40-49. [CrossRef]

44. Huber, B.; Hilbig, H.; Drewes, J.E.; Müller, E. Evaluation of concrete corrosion after short-and long-term exposure to chemically and microbially generated sulfuric acid. Cem. Concr. Res. 2017, 94, 36-48. [CrossRef]

45. ASTM C642-13. Standard Test Method for Density, Absorption, and Voids in Hardened Concrete; ASTM International: West Conshohocken, PA, USA, 2013.

46. Gutberlet, T.; Hilbig, H.; Beddoe, R.E. Acid attack on hydrated cement-Effect of mineral acids on the degradation process. Cem. Concr. Res. 2015, 74, 35-43. [CrossRef]

47. Min, H.; Song, Z. Investigation on the sulfuric acid corrosion mechanism for concrete in soaking environment. Adv. Mater. Sci. Eng. 2018, 2018, 3258123. [CrossRef]

48. Bertron, A.; Duchesne, J.; Escadeillas, G. Accelerated tests of hardened cement pastes alteration by organic acids: Analysis of the pH effect. Cem. Concr. Res. 2005, 35, 155-166. [CrossRef]

49. Khan, M.; Ali, M. Improvement in concrete behavior with fly ash, silica-fume and coconut fibres. Constr. Build. Mater. 2019, 203, 174-187. [CrossRef]

50. Gökçe, H.S.; Hatungimana, D.; Ramyar, K. Effect of fly ash and silica fume on hardened properties of foam concrete. Constr. Build. Mater. 2019, 194, 1-11. [CrossRef]

51. Pala, M.; Özbay, E.; Öztaş, A.; Yuce, M.I. Appraisal of long-term effects of fly ash and silica fume on compressive strength of concrete by neural networks. Constr. Build. Mater. 2007, 21, 384-394. [CrossRef]

52. Yazıc1, H. The effect of silica fume and high-volume Class $\mathrm{C}$ fly ash on mechanical properties, chloride penetration and freeze-thaw resistance of self-compacting concrete. Constr. Build. Mater. 2008, 22, 456-462. [CrossRef]

53. Wu, M.; Wang, T.; Wu, K.; Kan, L. Microbiologically induced corrosion of concrete in sewer structures: A review of the mechanisms and phenomena. Constr. Build. Mater. 2020, 239, 117813. [CrossRef]

54. Wu, H.L.; Zhang, D.; Du, Y.J.; Li, V.C. Durability of engineered cementitious composite exposed to acid mine drainage. Cem. Concr. Compos. 2020, 108, 103550. [CrossRef]

55. Mounanga, P.; Khelidj, A.; Loukili, A.; Baroghel-Bouny, V. Predicting $\mathrm{Ca}(\mathrm{OH})_{2}$ content and chemical shrinkage of hydrating cement pastes using analytical approach. Cem. Concr. Res. 2004, 34, 255-265. [CrossRef]

56. Hewlett, P.; Liska, M. (Eds.) Lea's Chemistry of Cement and Concrete; Butterworth-Heinemann: Oxford, UK, 2003 ; pp. 1-845.

57. Zhang, D.; Ghouleh, Z.; Shao, Y. Review on carbonation curing of cement-based materials. J. CO 2 Util. 2017, $21,119-131$. [CrossRef]

58. Supit, S.W.M.; Shaikh, F.U.A. Durability properties of high volume fly ash concrete containing nano-silica. Mater. Struct. 2015, 48, 2431-2445. [CrossRef]

59. Tang, W.C.; Wang, Z.; Liu, Y.; Cui, H.Z. Influence of red mud on fresh and hardened properties of self-compacting concrete. Constr. Build. Mater. 2018, 178, 288-300. [CrossRef] 